\title{
A Novel Loading Method for Doxycycline Liposomes for Intracellular Drug Delivery: Characterization of In Vitro and In Vivo Release Kinetics and Efficacy in a J774A.1 Cell Line Model of Mycobacterium smegmatis Infection ${ }^{\text {[S }}$
}

\author{
Rebekah K. Franklin, Sarah A. Marcus, Adel M. Talaat, Butch K. KuKanich, Ruth Sullivan, \\ Lisa A. Krugner-Higby, and Timothy D. Heath \\ Pharmacology, Clinical, Analytical, and Toxicological Services and the Department of Anatomy and Physiology, Kansas State \\ University, Manhattan, Kansas (B.K.K.); and Departments of Surgical Sciences (L.A.K.-H.), Pathobiological Sciences (R.S.), and \\ Comparative Biosciences (A.M.T., S.A.M.); School of Veterinary Medicine (R.S.); School of Pharmacy (T.D.H.); and Research \\ Animal Resources Center, University of Wisconsin, Madison, Wisconsin (R.K.F., L.A.K.-H., R.S.)
}

Received January 29, 2015; accepted June 1, 2015

\begin{abstract}
Doxycycline (doxy) is used in treating intracellular and extracellular infections. Liposomal (LE) antibiotics allow low-frequency dosing and extended efficacy compared with standard (STD) formulations. We developed a novel sulfuric acid-loading method for doxycycline liposomes (LE-doxy). We hypothesized that a single s.c. injection of LE-doxy would be detectable in serum for at least 2 weeks at concentrations equal to or better than STD-doxy and would be bactericidal in an in vitro Mycobacterium smegmatis infection of J774A.1 macrophage cells. Liposomes were encapsulated by sulfuric acid gradient loading, and release kinetics were performed in vitro and in vivo. LE-doxy made using $8.25 \mathrm{mg} / \mathrm{ml}$ doxycycline loaded for 24 hours achieved $\mathbf{9 7 . 7 7 \%}$ capture in 1,2-dipalmitoyl-snglycero-3-phosphocholine (DPPC) and $43.87 \%$ in sphingomyelin (sphing). Rats were injected s.c. with $50 \mathrm{mg} / \mathrm{kg} \mathrm{LE-doxy} \mathrm{or} 5 \mathrm{mg} / \mathrm{kg}$
\end{abstract}

STD-doxy, and serial blood samples were collected. Pharmacokinetics were analyzed using high-performance liquid chromatography. Liver and injection site skin samples were collected at euthanasia (4 weeks postinjection). Minimal histologic tissue reactions occurred after injection of STD (nonliposomal), DPPC, or sphing-doxy. DPPC-doxy had slightly faster in vitro leakage than sphing liposomes, although both were detectable at 264 hours. The mean residence time for DPPC was the highest (111.78 hours), followed by sphing ( 56.00 hours) and STD (6.86 hours). DPPC and sphing-doxy were detectable at $0.2 \mu \mathrm{g} / \mathrm{ml}$ in serum at 336 hours postadministration. LE-doxy was not toxic to J774A.1 cells in vitro and produced inhibition of viable Mycobacterium smegmatis at 24 and 48 hours. LE-doxy will require further testing in in vivo infection models.

\section{Introduction}

Doxycycline (doxy) is a second-generation tetracycline antibiotic approved for use in the United States since 1967 (Nelson and Levy, 2011). Doxy is a broad spectrum antibiotic used to treat a variety of human and animal diseases. Doxy is effective against bacteria, such as Coxiella burnetii and Borellia spp. (Nelson and Levy, 2011). It can be used to treat intracellular infections as diverse as Plasmodium falciparum, Chlamydia spp., and Mycoplasma spp., for which it is the drug of choice (Rolain et al., 2005; Zeidner et al., 2008; Nelson and Levy, 2011). Bacteria-infecting cells, such as macrophages, are challenging to treat due to the location of macrophages in the tissue

This work was supported in part by departmental funds from the Research Animal Resources Center, University of Wisconsin, Madison, Wisconsin; the Companion Animal Fund, School of Veterinary Medicine, University of Wisconsin, Madison, Wisconsin; a gift from Comfort Care for Animals, LLC; and the National Institutes of Health [Grant NIH-1R21Al090308].

dx.doi.org/10.1124/dmd.115.063602.

SThis article has supplemental material available at dmd.aspetjournals.org. and the antibiotic affinity for macrophages (Denis et al., 1990; Henao et al., 2007). Often, all of these bacterial infections require long-term, daily treatments, which may lead to poor compliance and underdosing with currently available formulations. The development of new delivery vehicles is important to both human and veterinary medicine. An ideal drug can be given at infrequent intervals, yet maintain a high level of efficacy during the treatment period. Both free and liposomal tetracycline and doxy have been explored in in vitro and in vivo models for their antichlamydial activities (Sangaré et al., 1998, 1999, 2001a,b; Selliah and Ravaoarinoro, 2004). Extended-release formulations of antibiotics have been used in veterinary medicine for many years. For example, an oxytetracycline formulation, Liquamycin LA200 (Zoetis, Inc., Kalamazoo, MI), which can be administered every 48 hours, has been used in cattle (Kumar and Malik, 1998). However, a particular formulation may not have the same efficacy across species. Cefovecin, Convenia (Zoetis, Inc.), a cephalosporin formulation that lasts for 2 weeks, has found wide use in companion animals in the management of chronic dermatologic diseases. However, Convenia relies on resorption of the drug in the renal proximal tubule in dogs and cats for its extended action, as opposed to liposomal

ABBREVIATIONS: AUC, area under the curve; doxy, doxycycline; DPPC, 1,2-dipalmitoyl-sn-glycero-3-phosphocholine; sphing, sphingomyelin; LE, liposomal; LE-doxy, liposomal encapsulated doxycycline; MRT, mean residence team; SPE, solid phase extraction; sphing, sphingomyelin; STD, standard. 
formulations, which would be expected to have an extended release of the drug (Stegemann et al., 2006a,b). Nonhuman primates do not reabsorb this drug in the kidney, and its half-life is not extended in these species (Raabe et al., 2011).

In human medicine, tetracyclines are also used to treat skin disorders that do not necessarily have a bacterial origin ( $\mathrm{Gu}$ et al., 2012). There are formulations of extended-release doxycycline hyclate for human use, but they have not been developed or dosed for their bacteriocidal activities (Sapadin and Fleischmajer, 2006; Gu et al., 2012). There is evidence that doxy has anti-inflammatory properties at subantimicrobial doses and may cause inhibition of phospholipase A2, inhibition of the expression of nitric oxide synthetase, accelerated degradation of nitric oxide synthase, inhibition of pathologic matrix metalloproteinase activity, and free radical scavenging (Sapadin and Fleischmajer, 2006; Federici, 2011; Gu et al., 2012). These activities are used to treat multifactorial inflammatory diseases, such as acne and rosacea, in human beings (Sapadin and Fleischmajer, 2006; Federici, 2011; Gu et al., 2012).

Liposomes have long been studied as a drug delivery system (Hunt et al., 1979). Variations in liposome composition, formation, and loading methodology may lead to strikingly different drug concentrations and release kinetics for a particular drug (Hunt et al., 1979; Omri et al., 1995; Omri and Ravaoarinoro, 1996; Sangaré et al., 1998; Krugner-Higby et al., 2003, 2009; Smith et al., 2003, 2013; Budai et al., 2009). Our laboratory has developed a novel liposome loading methodology (Heath et al., 2014). We hypothesized that formulations of liposomal doxy (LE-doxy) prepared using this technology would be detectable in serum after a single s.c. injection for at least 2 weeks at concentrations equal to or better than that of standard (STD) injectable doxy. We hypothesized that LE-doxy would be bacteriocidal and preserve cell viability in an in vitro model of Mycobacterium smegmatis infection of murine origin J774A.1 macrophage line cells.

\section{Materials and Methods}

Animals. The University of Wisconsin-Madison School of Veterinary Medicine Animal Care and Use Committee approved the animal protocol. Experiments were performed on 17 adult August Copenhagen Irish (ACI) male and female rats. Sentinel rats in the same facility tested free of ecto- and endoparasites and were serologically negative for titers to the following antigens: Mycoplasma pulmonis, Sendai, sialodacryoadenovirus, rat corona virus, Kilham virus of rats, Toolans $\mathrm{H}-1$ virus, rat parvovirus, and Clostridium piliforme.

Rats were housed in polypropylene caging and were provided a commercial rat diet (Teklad, 7002, 6\% fat mouse and rat diet; Harlan, Madison, WI) and water ad libitum. Rats were weighed at the beginning of the experiment. All blood collection and injection of drugs were performed under isoflurane anesthesia administered via facemask to effect. Four weeks after drug injection, rats were deeply anesthetized with isoflurane and euthanized with an intracardiac injection of commercially available euthanasia solution (Fatal Plus; Vortech Pharmaceuticals, Dearborn, MI). Samples of liver and the injected rear legs were collected. Liver samples were frozen at $-20^{\circ} \mathrm{C}$ until evaluated for doxy concentration, and rear legs were marked with an identification tag and placed in $10 \%$ neutral buffered formalin until histopathology was performed.

Liposome Encapsulation by Sulfuric Acid Gradient Loading. A mixture of $80 \mu \mathrm{mol}$ 1,2-dipalmitoyl-sn-glycero-3-phosphocholine (DPPC) or $80 \mu \mathrm{mol}$ sphingomyelin (sphing) and $40 \mu \mathrm{mol}$ cholesterol (Avanti Polar Lipids, Alabaster, AL) was dried by removing chloroform, dissolved in $1 \mathrm{ml}$ of sterile tert-butanol (Sigma-Aldrich, St. Louis, MO) by heating to $55^{\circ} \mathrm{C}$ in a water bath, frozen in a dry ice-isopropanol mixture, and lyophilized for 24 hours. The resulting microporous lipid masses were stored at $-20^{\circ} \mathrm{C}$ until use. One milliliter of 3.0 M sulfuric acid (AMEND Drug and Chemical Company, Irvington, NJ), was added to the lipid mass and incubated for 30 minutes at $50^{\circ} \mathrm{C}$. A 250- $\mu$ l aliquot was dispensed into each of the four separate tubes. Doxycycline hyclate (Sigma-Aldrich) was dissolved in sterile water at a concentration of either 33 or $8.25 \mathrm{mg} / \mathrm{ml}$, and $250 \mu \mathrm{l}$ was added to the lipid swelled in sulfuric acid, followed by $53.6 \mu \mathrm{l}$ of $5 \mathrm{M} \mathrm{NaOH}$ in $1 \mathrm{M}$ citrate buffer. The addition of $\mathrm{NaOH} /$ citrate raised the $\mathrm{pH}$ of the extra-liposomal compartment to $\mathrm{pH} 3.9$, creating a $\mathrm{pH}$ gradient that drove the loading of the doxy. The maximum $\mathrm{pH}$ was determined experimentally, and $\mathrm{pH} 3.9$ was selected because higher $\mathrm{pH}$ values resulted in precipitation of the doxy. A single tube of doxy liposomes was loaded either on a rotating shaker for 24 hours at $22^{\circ} \mathrm{C}$ or in a water bath at $55^{\circ} \mathrm{C}$ for 1 hour. The liposomes were diluted in $4 \mathrm{ml}$ of normal saline (Baxter International, Deerfield, IL), sedimented at $1000 \mathrm{~g}$ for 10 minutes in a centrifuge, and resuspended in $2 \mathrm{ml}$ of normal saline. The loading efficiency was determined by solubilizing the aqueous liposome suspension in chloroform/methanol at a volumetric ratio of 1:3:1 water/methanol/chloroform.

Particle Size. The particle size for the liposomes was determined using a Malvern Nano Series Zetasizer (Malvern Instruments, Malvern, UK). An aliquot of the liposomal preparation was suspended in $0.9 \% \mathrm{w} / \mathrm{v} \mathrm{NaCl}$. The samples were read at $25^{\circ} \mathrm{C}$.

Thin Layer Chromatography. To determine whether the preparation of liposomes by acid loading led to any degradation of the lipid components, a sample of liposomes prepared from DPPC and cholesterol was extracted using the method of Bligh and Dyer (1959). Silica gel 60 thin layer chromatography plates $(250 \mu)$ (EMD Millipore, Billerica, MA) were first activated by heating on a hot plate for 2 minutes. The extracted lipid was spotted on the plate together with standards for cholesterol and DPPC. The plate was developed in a mixture of chloroform/methanol/ammonium hydroxide 65:25:4 v/v/v. The developed plate was dried and stained with iodine vapor.

In Vitro Release Kinetics of LE-Doxy Formulations. Cellulose dialysis tubing (Fisher Scientific, Pittsburgh, PA) was prepared by boiling in three changes of EDTA and sodium carbonate. The tubing was rinsed in distilled water and stored in $30 \%$ ethanol at $5^{\circ} \mathrm{C}$ until use, as previously described (Krugner-Higby et al., 2003). Sections of tubing were tied at one end and filled with $100 \mu \mathrm{l}$ of DPPC/cholesterol LE-doxy preparations made using 33 or $8 \mathrm{mg} / \mathrm{ml}$ doxy solutions and $900 \mu \mathrm{l}$ of normal saline. The ends were tied off, and the bag was placed in $9.0 \mathrm{ml}$ of saline in a 50-ml conical centrifuge tube. Tubes were prepared in duplicate, covered with tin foil, and placed on a rotary shaker at $22^{\circ} \mathrm{C}$. At selected time points, an aliquot of buffer was removed, placed in a cuvette, and then absorbance at 345 and $480 \mathrm{~nm}$ was determined by a spectrophotometer. The aliquot of the buffer was returned to the centrifuge tube, and the tubes were covered with foil and returned to the shaker until the next time point.

Blood Draws. Rats were placed under isoflurane anesthesia and kept warm on a reheatable gel pad covered with surgical drape. A 3-cc syringe and a 22gauge needle were used to draw 0.5 -ml blood samples from the ventral tail artery. Blood was placed into a $1.5-\mathrm{ml}$ microcentrifuge tube containing glass shards to provide a nidus for clot formation and retraction and was centrifuged. Serum was separated from formed elements and frozen at $-20^{\circ} \mathrm{C}$ until assayed. Blood was drawn prior to injection from each of the 17 rats. Blood samples were drawn at 1 hour and 4, 8, and 24 hours in the rats administered STD-doxy. Blood samples were drawn from the rats administered LE-doxy in DPPC or sphing at 1 hour and 4, 24, 48, 72, 96, 168 (7 days), and 336 (14 day) hours after injection.

Injections. STD-doxy was dosed s.c. at $5 \mathrm{mg} / \mathrm{kg}$, and LE-doxy (DPPC or sphing) was dosed at $50 \mathrm{mg} / \mathrm{kg}$ and given s.c. using a 22-gauge needle. The rat was placed under isoflurane anesthesia, and the upper thigh and hip area was clipped and swabbed with alcohol. Rats were allowed to recover from anesthesia and were monitored until awake. The rats were observed for any signs of discomfort in the injected site (abnormal gait, shaking, or other abnormal movements).

Assay for In Vivo Pharmacokinetics of LE-Doxy. Serum samples were analyzed for doxy using high-pressure liquid chromatography (Shimadzu Prominence; Shimadzu Scientific Instruments, Columbia, MD) with triple quadruple mass spectrometry (API 2000; Applied Biosystems, Foster City, CA). A protein precipitation method was used for sample processing, in which a 0.1-ml sample or standard was added to a 0.4-ml internal standard solution (oxytetracycline $0.5 \mu \mathrm{g} / \mathrm{ml}$ in methanol with $0.1 \%$ formic acid). The processed samples were vortexed for 5 seconds and then centrifuged for 5 minutes at $15,000 \mathrm{~g}$. The supernatant was transferred to an injection vial. The mobile phase 
consisted of $0.1 \%$ formic acid in deionized water (A) and acetonitrile (B). The mobile phase gradient started at $100 \%$ A from 0 to 0.5 minutes, with a linear gradient to $40 \% \mathrm{~A}$ at 3.5 minutes, followed by a linear gradient to $100 \% \mathrm{~A}$ at 4.5 minutes, with a total run time of 6.5 minutes. Separation was achieved at $40^{\circ} \mathrm{C}$ with a $50 \times 2.1 \mathrm{~mm} 5 \mu \mathrm{M}$ column (Allure PFP Propyl; Restek Corporation, Bellefonte, PA). The qualifying and quantifying ions for doxy were mass to charge $(\mathrm{m} / \mathrm{z}) 445$ and 428 , respectively. The qualifying and quantifying ions $(\mathrm{m} / \mathrm{z})$ for oxytetracycline were 461 and 426 , respectively. Plasma standards (in untreated rat plasma) included a blank and ranged from 0.05 to $5 \mu \mathrm{g} / \mathrm{ml}$, with the lower limit of quantification being $0.05 \mu \mathrm{g} / \mathrm{ml}$. The accuracy of the assay was determined with replicates of three at $0.05,0.1,1$, and $10 \mu \mathrm{g} / \mathrm{ml}$ and was $100.1,97.4,97.2$, and $96.4 \%$, respectively. The coefficients of variation on the replicates of three at $0.05,0.1,1$, and $10 \mu \mathrm{g} / \mathrm{ml}$ were $11,6,16$, and $7 \%$, respectively.

Liver tissue concentrations of doxy were determined by Liquid Chromatography Mass Spectroscopy, as previously described for plasma. The untreated rat liver was fortified with doxy at zero and six concentrations ranging from 0.1 to $50 \mu \mathrm{g} / \mathrm{ml}$ for the standard curve. The tissue standard curve was accepted if the measured concentration in at least four out of six standards was within 15\% of the actual concentration. Approximately $1 \mathrm{~g}$ of tissue was weighed within $0.02 \mathrm{~g}$ and added to the internal standard solution $(500 \mathrm{ng} / \mathrm{ml}$ oxytetracycline final concentration) and homogenized (Polytron PT 10-35 GT; Kinematica, Inc., Bohemia, NY). The homogenates were vortexed and held for 1 hour at $4^{\circ} \mathrm{C}$. Two milliliters of $20 \%$ trichloroacetic acid solution were added to the homogenate and vortexed, followed by $10 \mathrm{ml}$ of citrate buffer $(10 \mathrm{mM}, \mathrm{pH} 4)$ and then it was sonicated for 10 minutes, followed by centrifugation at $2500 \mathrm{~g}$ for 20 minutes. One milliliter of the supernatant then underwent solid phase extraction (SPE) (Strata C18, $3 \mathrm{ml}$; Phenomenex, Torrance, CA). The SPE was conditioned with $1.25 \mathrm{ml}$ of methanol, followed by $1.25 \mathrm{ml}$ of deionized water. The sample or standard was loaded, the SPE cartridges were washed with 2.5- $\mathrm{ml} 5 \%$ methanol in deionized water, and $1.25 \mathrm{ml}$ of methanol was used for elution. The eluate was evaporated to dryness under an air stream at $40^{\circ} \mathrm{C}$. The evaporated samples and standards were then reconstituted with $0.2 \mathrm{ml}$ of methanol.

Pharmacokinetic Analysis. Pharmacokinetic analysis was performed using computer software (WinNonlin 5.2; Pharsight Corporation, Mountain View, $\mathrm{CA})$. The parameters determined included area under the curve $\left(\mathrm{AUC}_{\mathrm{all}}\right)$, maximum serum concentration $\left(C_{\max }\right)$, mean residence time $\left(\mathrm{MRT}_{\text {last }}\right)$, and time to maximum serum concentration $\left(T_{\max }\right)$ (Julious and Debarnot, 2000). Geometric mean, minimum, median, and maximum were calculated for each parameter.

Histology. The fixed tissue was cut, placed in cassettes, and placed into $10 \%$ neutral buffered formalin until processed. Slides were stained with H\&E. The pathologist reading the slides was blinded to the group and origin of the tissues.

Cytotoxicity and Bactericidal Properties of LE-Doxy: Cytotoxicity Assay. J774A.1 cells were seeded into 24-well culture plates at a density of $1.8 \times 10^{5}$ cells/well. Cells were allowed to adhere to the plates for 16 hours at $37^{\circ} \mathrm{C}$ in a humidified $5 \% \mathrm{CO}_{2}$ atmosphere. The culture medium, RPMI1640 plus $10 \%$ fetal bovine serum, was removed by aspiration, and the cells were overlaid with the same medium supplemented with different concentrations of either STD or DPPC LE-doxy. Treatments were done in triplicate, and medium without the drug was used as a control. Plates were incubated for 24 and 48 hours, and cells were harvested using a cell scraper, stained with Trypan blue, and counted using a hemocytometer.

In Vitro Activity against $\boldsymbol{M}$. smegmatis. J774A.1 cells $\left(1.8 \times 10^{5} /\right.$ well $)$ were allowed to adhere to 24-well plates, as described above for the cytotoxicity assay. The medium was removed by aspiration, and the cells were infected with $M$. smegmatis in RPMI medium $+10 \%$ fetal bovine serum (Ghosh et al., 2013) at a multiplicity of infection of 1 bacterium/cell. After 3 hours, extracellular bacilli were washed away, and STD or DPPC LE-doxy was added in five concentrations. The medium without the drug was used as a negative control. The efficacy of STD and DPPC LE-doxy was determined by two methods, colony-forming unit counts were taken at 24 and 48 hours to determine the number of viable bacteria and cover slips with adherent, and infected J774A.1 cells were stained with propidium iodide for fluorescence microscopy counts. Bacteria inside the cells were stained using auramine. The total cells and infected cells were counted at 24 and 48 hours. Replicates were done in triplicate wells. Plates were not counted if microscopic growth was so heavy that individual colonies could not be identified. The microplate Alamar blue assay was used to determine the efficacy of STD and DPPC LE-doxy in a cell-free system as a comparison (Franzblau et al., 1998).

Statistical Analysis. The Mann-Whitney test was used to compare the serum and liver concentrations of doxy and to compare cell counts and numbers of colony-forming units between and within groups. Fisher's exact test was used to compare the probability of histologic lesions in skin samples obtained from the rats at necropsy.

\section{Results}

Sulfuric Acid Loading. The optimal concentration of doxy loaded into the DPPC liposomes was obtained using $4 \mathrm{ml}$ of $8.25 \mathrm{mg} / \mathrm{ml}$ doxy loaded into liposomes containing 3.0 M sulfuric acid loaded for 24 hours at $22^{\circ} \mathrm{C}$, with a percentage capture of $97.77 \%$. Doxy loading using $1 \mathrm{ml}$ of $33 \mathrm{mg} / \mathrm{ml}$ produced a preparation with $14.77 \%$ capture. Doxy loading approached $100 \%$ using $4 \mathrm{ml}$ of doxy solution at a concentration of $8.25 \mathrm{mg} / \mathrm{ml}$, and this method was used for loading the liposome preparations used for pharmacokinetics studies in rats. Loading the same two concentrations for 1 hour and 48 hours at 22 or $55^{\circ} \mathrm{C}$ did not improve the milligrams of drug captured (Table 1). Optimal loading conditions for doxy loaded in 3.0 M sulfuric acidcontaining liposomes with a sphing/cholesterol shell were found to be $4 \mathrm{ml}$ of $8.25 \mathrm{mg} / \mathrm{ml}$ for 24 hours at $22^{\circ} \mathrm{C}$. The average percentage capture $(n=3)$ was 43.87 .

Particle Size. The $Z$-average diameter was $3178 \mathrm{~nm}$.

Thin Layer Chromatography. Analysis of extracted lipids by thin layer chromatography showed the presence of two additional spots, indicating that significant amounts of breakdown products of DPPC were present after preparation.

In Vitro Leakage. Leakage from dialysis bags containing DPPC/ cholesterol liposomes loaded at $33 \mathrm{mg} / \mathrm{ml}$ was faster than for DPPC LE-doxy loaded using $8.25 \mathrm{mg} / \mathrm{ml}$ doxy (Fig. 1A). The DPPC LEdoxy made with $8.25 \mathrm{mg} / \mathrm{ml}$ leaked less than $45 \%$ of the loaded doxy at the 100-hour time point (Fig. 1A), whereas the DPPC LE-doxy made using $33 \mathrm{mg} / \mathrm{ml}$ leaked almost $70 \%$ of its loaded doxy by the same time point. Leakage of DPPC LE-doxy loaded using $4 \mathrm{ml}$ of 8.25 $\mathrm{mg} / \mathrm{ml}$ (18.4\% in 264 hours) was slower compared with sphing LEdoxy loaded with the same concentration of doxycycline $(21.2 \%$ at 264 hours) (Fig. 1B). Both LE-doxy in DPPC and sphing would make viable preparations to perform initial pharmacokinetics studies in rats.

Pharmacokinetics in ACI Rats. After injection, time to peak concentration $\left(T_{\max }\right)$ was 1 hour for DPPC, sphing, and STD-doxy (Table 2). The MRT of DPPC was highest at 111.78 hours, followed by sphing (56.00 hours) and STD-doxy (6.86 hours). Serum samples from rats administered sphing LE-doxy had the longest time for the area under the concentration time curve (120 hours), with DPPC LEdoxy at 70.39 hours and STD at 6.36 hours. Serum peak concentration

TABLE 1

Doxycycline loading using $3.0 \mathrm{M}$ sulfuric acid-loaded $20 \mu \mathrm{M}$ DPPC/ cholesterol liposomes

\begin{tabular}{cc}
$\begin{array}{c}\text { Time/Temperature/Input Concentration } \\
\text { of Doxycycline }{ }^{a}\end{array}$ & Milligrams Captured \\
\hline${ }^{\rho}{ }^{\rho}$ C per $m g / m l$ & $\%$ \\
$1 / 55 / 33$ & $0.401(4.86)$ \\
$1 / 55 / 8.25$ & $1.54(74.69)$ \\
$24 / 22 / 33$ & $1.21(14.77)$ \\
$24 / 22 / 8.25$ & $2.02(97.77)$ \\
$48 / 22 / 33$ & $3.199(38.77)$ \\
$48 / 22 / 8.25$ & $1.44(69.57)$
\end{tabular}

${ }^{a}$ Loading conditions were 1,24 , or 48 hours on the shaker at either 55 or $22^{\circ} \mathrm{C}$. A doxycycline concentration of either 8.25 or $33 \mathrm{mg} / \mathrm{ml}$ was added to the liposome mixture. 

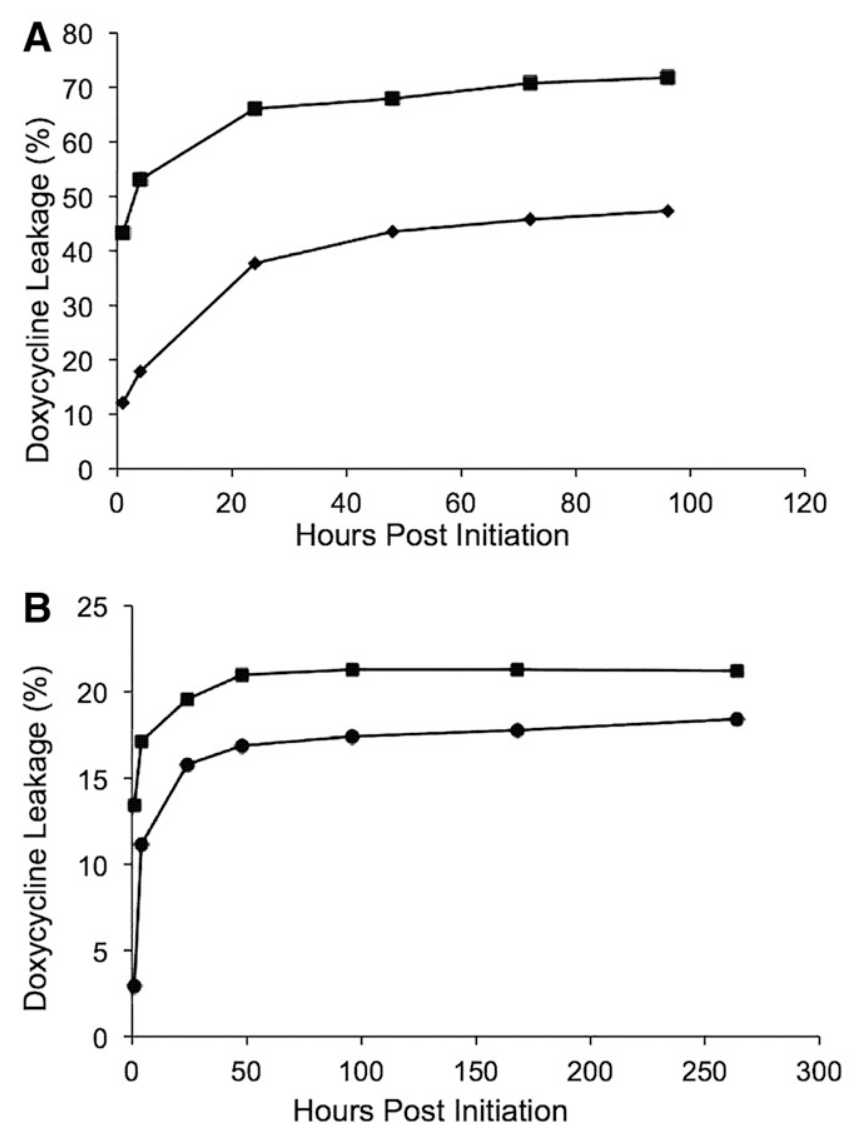

Fig. 1. In vitro leakage of different formulations of LE-doxy. In vitro leakage of liposomes loaded using $33 \mathrm{mg} / \mathrm{ml}$ doxy (squares) or $8.25 \mathrm{mg} / \mathrm{ml}$ doxy (diamonds) in DPPC-cholesterol liposomes (A). In vitro leakage comparison between liposomes composed of sphing cholesterol (squares) versus DPPC cholesterol (circles) (B).

was highest in sphing LE-doxy $(6.59 \mu \mathrm{g} / \mathrm{ml})$, followed by DPPC LEdoxy $(2.05 \mu \mathrm{g} / \mathrm{ml})$ and $\operatorname{STD}(0.74 \mu \mathrm{g} / \mathrm{ml})$. Figure 2 is a graphical representation of the serum concentrations. All formulations were at their peak plasma concentration by 1 hour. The steepest declines occurred in the first 24 hours, with the slope becoming much slower for DPPC and sphing LE-doxy after about 72 hours, continuing at roughly the same concentration until the last time point of 336 hours. The DPPC plasma concentration rises slightly over that of sphing LEdoxy at 168 hours, maintaining a higher concentration through the last time point. The peak concentration $\left(C_{\max }\right)$ of DPPC LE-doxy was 2.01 $\mu \mathrm{g} / \mathrm{ml}$. $C_{\max }$ of sphing LE-doxy was $6.49 \mu \mathrm{g} / \mathrm{ml}$ and that of STD-doxy

TABLE 2

Pharmacokinetics of nonencapsulated STD-doxy and DPPC or sphing LE-doxy liposomes in rat serum

\begin{tabular}{lllrrrr}
\hline Treatment & Parameter & Units & Geometric Mean & Minimum & Median & Maximum \\
\hline DPPC & $\mathrm{AUC}_{\text {all }}$ & $\mathrm{h}^{*} \mu \mathrm{g} / \mathrm{ml}$ & 69.34 & 57.30 & 66.98 & 90.28 \\
Sphing & $\mathrm{AUC}_{\text {all }}$ & $\mathrm{h}^{*} \mu \mathrm{g} / \mathrm{ml}$ & 118.96 & 89.88 & 127.56 & 132.51 \\
$\mathrm{STD}$ & $\mathrm{AUC}_{\mathrm{all}}$ & $\mathrm{h}^{*} \mu \mathrm{g} / \mathrm{ml}$ & 6.22 & 4.81 & 6.19 & 8.27 \\
$\mathrm{DPPC}$ & $C_{\max }$ & $\mu \mathrm{g} / \mathrm{ml}$ & 2.01 & 1.42 & 2.25 & 2.28 \\
Sphing & $C_{\max }$ & $\mu \mathrm{g} / \mathrm{ml}$ & 6.49 & 4.81 & 6.58 & 8.01 \\
STD & $\mathrm{Cmax}_{\max }$ & $\mu \mathrm{g} / \mathrm{ml}$ & 0.72 & 0.55 & 0.76 & 0.89 \\
DPPC & MRT $_{\text {last }}$ & Hours & 111.78 & 89.62 & 111.53 & 141.66 \\
Sphing & MRT $_{\text {last }}$ & Hours & 56.00 & 45.72 & 54.36 & 73.80 \\
STD & MRT $_{\text {last }}$ & Hours & 6.86 & 6.27 & 6.87 & 7.51 \\
DPPC & $T_{\max }$ & Hours & 1.00 & 1.00 & 1.00 & 1.00 \\
Sphing & $T_{\max }$ & Hours & 1.00 & 1.00 & 1.00 & 1.00 \\
STD & $T_{\max }$ & Hours & 1.00 & 1.00 & 1.00 & 1.00 \\
\hline
\end{tabular}

was $0.72 \mu \mathrm{g} / \mathrm{ml}$. The plateau concentrations for DPPC and sphing LEdoxy were $\geq 0.2 \mu \mathrm{g} / \mathrm{ml}$.

Liver samples were collected at euthanasia of the rats 4 weeks after initial injections were performed. The average concentration of STDdoxy in the liver was $0.093 \mu \mathrm{g} / \mathrm{g}$ (S.D. \pm 0.0048). The average concentration for sphing LE-doxy was $0.174 \mu \mathrm{g} / \mathrm{g}$ (S.D. \pm 0.0505 ) and that for DPPC LE-doxy was $0.169 \mu \mathrm{g} / \mathrm{g}$ (S.D. \pm 0.0850). Comparisons between hepatic concentrations of doxy in rats administered STD-doxy and sphing LE-doxy $(P=0.08$; MannWhitney Test) and between rats administered STD-doxy and DPPC LE-doxy $(P=0.086$; Mann-Whitney Test $)$ approached, but did not achieve, statistical significance. Hepatic concentrations of doxy in rats administered DPPC or sphing LE-doxy were not significantly different from one another $(P=0.88$; Mann-Whitney Test $)$.

Gross Appearance of Injection Sites. A small crust was noted on one rat injected with STD-doxy, a second rat injected with STD-doxy had hardened skin and a crust with a superficial slough, and one rat injected with DPPC LE-doxy had a minor crusted lesion at the injection site. None of the rats injected with sphing LE-doxy had grossly visible lesions.

Skin Histology. Histopathologic examination was performed on the injected sites, noninjected skin, and s.c. tissues from the same leg of all rats in all groups. The pathologist who evaluated the samples (R.S.) was blinded to the group assignments. Skin samples were classified as having no lesions, histiocytosis, or miscellaneous inflammation (Table 3). Rats injected with STD-doxy, DPPC LE-doxy, or sphing LE-doxy had mild inflammatory lesions in both injected and noninjected skin samples. There were very few comparisons between lesions that were statistically significantly different from one another (Table 3) (Fisher's exact test). The predominant lesion present in rats administered DDPC LE-doxy, sphing LE-doxy, or blank salinecontaining liposomes was a histiocytic infiltrate with foamy cytoplasm and intensely stained nuclei (Fig. 3, A, C, D, and F). Low numbers of lymphocytes were sometimes in a few scattered regions or around vessels in the areas of histiocytosis. One sphing LE-doxy-injected animal exhibited moderate lymphocytic infiltrates. The histology of the skin of the DPPC LE-doxy-injected animal with the grossly noted skin crust exhibited epidermal hyperplasia and adnexal atrophy along with connective tissue fibroplasia and granulation tissue formation, which is consistent with a healing wound overlying histiocytosis.

There was a wide range of lesion extent, and many injected rats did not have histiocytic lesions (Fig. 3, B and E). The two rats administered standard doxy that had grossly visible inflammatory lesions in the first week postinjection did not have any lesions apparent during collection at 4 weeks postinjection (data not shown).

Cytotoxicity and Bacteriocidal Properties of LE-Doxy: In Vitro Model of Cell-Associated $M$. smegmatis Infection. The untreated control wells grew to 600,000 J774A.1 cells after 24 hours of incubation (Fig. 4A). There were significantly more live, uninfected cells in the wells containing STD-doxy compared with DPPC LE-doxy at the 0.05 $\mu \mathrm{g} / \mathrm{ml}$ concentration, in the control $(0 \mu \mathrm{g} / \mathrm{ml})$ at 24 hours, and in the wells containing STD-doxy compared with DPPC LE-doxy at 0.01 and $0.25 \mu \mathrm{g} / \mathrm{ml}$ at 48 hours (Fig. 4 , A and B). There were significantly fewer live J774A. 1 cells in the wells containing $6.25 \mu \mathrm{g} / \mathrm{ml}$ compared with the control $(0 \mu \mathrm{g} / \mathrm{ml})$ at 24 hours. All concentrations of STD and DPPC LEdoxy $(0.01,0.05,0.25,1.25$, and $6.25 \mu \mathrm{g} / \mathrm{ml})$ were noncytotoxic to uninfected J774A.1 cells (Fig. 4, A and B).

Concentrations of doxy used in M. smegmatis-infected J774A.1 cells were based on the results of a microplate assay, indicating that both STD and DPPC LE-doxy had an Mean Inhibitory Concentration (MIC) of $8-16 \mu \mathrm{g} / \mathrm{ml}$, respectively, for $M$. smegmatis grown in Middlebrook $7 \mathrm{H} 9$ liquid medium (data not shown). Live-infected cells 


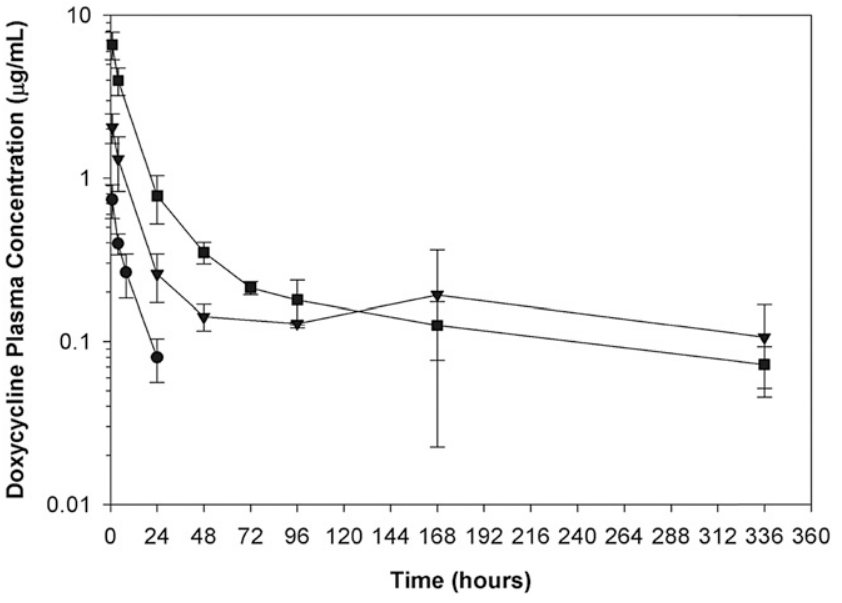

Fig. 2. Serum concentrations and pharmacokinetic data in ACI rats. Rats were administered STD-doxy at $5 \mathrm{mg} / \mathrm{kg}$ (circles), DPPC LE-doxy (squares), or sphing LE-doxy (triangles) preparations at $50 \mathrm{mg} / \mathrm{kg}$. All formulations were administered s.c. Blood samples were taken before injection for control and from 1 to 336 hours (14 days) after injection. Serum was separated, removed, and stored at $-20^{\circ} \mathrm{C}$ until assayed by high-performance liquid chromatography.

were present in all of the treatments at 24 hours. There were significantly more live cells in the wells containing STD-doxy compared with LE-doxy in the wells containing $1,4,8$, and $16 \mu \mathrm{g} / \mathrm{ml}$ and control $(0 \mu \mathrm{g} / \mathrm{ml})$ at 24 hours. The number of live-infected cells in the wells containing 8 and $16 \mu \mathrm{g} / \mathrm{ml}$ STD-doxy was significantly lower than the number of cells in the control $(0 \mu \mathrm{g} / \mathrm{ml})$ at 24 hours (Fig. 4C). There were no live cells left in the wells containing $1 \mu \mathrm{g} / \mathrm{ml}$ STD-doxy or in the $0 \mu \mathrm{g} / \mathrm{ml}$ control at 48 hours, but the wells containing $1 \mu \mathrm{g} / \mathrm{ml}$ DPPC LE-doxy and blank liposomes contained live cells at that time point (Fig. 4D). There were significantly more live-infected cells in the wells containing $2 \mu \mathrm{g} / \mathrm{ml}$ STD-doxy compared with DPPC LE-doxy, but there were significantly more live-infected cells in the wells containing $8 \mu \mathrm{g} / \mathrm{ml}$ DPPC LE-doxy compared with STD-doxy. There were significantly fewer liveinfected cells in the wells containing 4,8 , and $16 \mu \mathrm{g} / \mathrm{ml}$ STD-doxy compared with $2 \mu \mathrm{g} / \mathrm{ml}$ STD-doxy (the first concentration for which there were live cells to count) at 48 hours (Fig. 4D).

The negative control and concentrations from 1 to $16 \mu \mathrm{g} / \mathrm{ml} \mathrm{STD} \mathrm{or}$ DPPC LE-doxy had between 10 and 20\% infected cells at 24 hours
(Fig. 5A). There was a significantly larger percentage of infected cells in the wells containing control blank liposomes compared with the $0 \mu \mathrm{g} / \mathrm{ml}$ control for STD-doxy at 24 hours. However, there was a significantly lower percentage of infected cells in the wells containing DPPC LE-doxy at 2 and $4 \mu \mathrm{g} / \mathrm{ml}$ compared with STDdoxy at 24 hours (Fig. 5A). There was a higher percentage of infected cells in wells containing 2,4 , and $16 \mu \mathrm{g} / \mathrm{ml}$ compared with the $0 \mu \mathrm{g} / \mathrm{ml}$ control at 24 hours (Fig. 5A). There were no surviving cells to count in the untreated wells $(0 \mu \mathrm{g} / \mathrm{ml}$ STD-doxy) or in the wells treated with $1 \mu \mathrm{g} / \mathrm{ml} \mathrm{STD-doxy} \mathrm{at} 48$ hours (Fig. 5B). There was a significantly larger percentage of infected cells in the wells containing STD-doxy at $16 \mu \mathrm{g} / \mathrm{ml}$ at 48 hours (Fig. 4B). The MIC 90 for intracellular M. smegmatis in the J774A.1 cells of both STD and DPPC LE-doxy was $2 \mu \mathrm{g} / \mathrm{ml}$ (Fig. 5C). The MIC 90 for intracellular M. smegmatis in this cell line for DPPC LE-doxy at 48 hours was $16 \mu \mathrm{g} / \mathrm{ml}$ (Fig. 5D). The STD-doxy-treated cells reached close to the MIC 50 at $16 \mu \mathrm{g} / \mathrm{ml}$.

\section{Discussion}

Sulfuric acid created an effective gradient for movement of the drug across the liposomes, with less leakage than previous formulations of liposomal LE-doxy (Sangaré et al., 1998). Loading for 24 hours at room temperature and at $8.25 \mathrm{mg} / \mathrm{ml}$ gave us the optimal capture per micromolar of lipid (Table 1). Sulfuric acid-loaded LE-doxy in DPPC or sphing produced an extended release of at least 2 weeks in vivo in rats (Fig. 2; Table 2), and the DPPC formulation had antimicrobial activity against $M$. smegmatis at 48 hours (Fig. 5).

We developed a novel loading methodology, resulting in liposomes with higher drug loading and longer retention times than passive aqueous capture (Omri and Ravaoarinoro, 1996; Omri et al., 1995; Sangaré et al., 1998, 1999, 2001a,b). The effectiveness of a gradientloading system is highly dependent on the chemistry of the drug being loaded, its interactions with the liposomal membrane, and the compound(s) used to form the gradient. Gradient-loading systems in response to a $\mathrm{pH}$ gradient have been developed for ciprofloxacin and other drugs, but the previously described methods for establishing the gradient and loading the liposomes differ from the method described in the current manuscript (Maurer et al., 1998; Maurer-Spurej et al., 1999). Our loading and leakage results were better than published LEdoxy formulations formed by passive aqueous capture (Sangaré et al., 1998, 1999, 2001a,b) (Tables 1 and 4). Our loading efficiency is

TABLE 3

Results of histologic evaluation of skin samples obtained at 4 weeks postinjection from ACI rats injected s.c. with STD or LE-doxy

\begin{tabular}{|c|c|c|c|}
\hline Group & No Lesions/Number of Samples & Histiocytosis/Number of Samples & $\begin{array}{l}\text { Miscellaneous Inflammation/ } \\
\text { Number of Samples }\end{array}$ \\
\hline & $\%$ & $\%$ & $\%$ \\
\hline \multicolumn{4}{|l|}{ STD-doxy } \\
\hline Injected & $4 / 8(50)^{a}$ & $0 / 8(0)$ & $2 / 8(25)$ \\
\hline Noninjected & $2 / 8(25)$ & $0 / 8(0)$ & $1 / 8(12.5)$ \\
\hline \multicolumn{4}{|l|}{ DPPC } \\
\hline Injected & $0 / 14(0)^{a}, b$ & $5 / 14(35.7)$ & $2 / 14(14.3)$ \\
\hline Noninjected & $3 / 14(21)^{c}$ & $0 / 14(0)$ & $5 / 14(35.7)$ \\
\hline \multicolumn{4}{|l|}{ Sphing } \\
\hline Injected & $4 / 12(33)^{b}$ & $3 / 12(25)$ & $0 / 12(0)$ \\
\hline Noninjected & $8 / 12(67)^{c}$ & $1 / 12(8.3)$ & $0 / 12(0)$ \\
\hline
\end{tabular}

${ }^{a}$ Injected skin samples from rats that received STD-doxy had a greater probability of having no lesions compared with injected samples receiving LE-doxy in DPPC liposomes (Fisher's exact test; $P=0.019$ ).

${ }^{b}$ Injected skin samples from rats that received LE-doxy in sphing liposomes had a marginally greater probability of having a lesion compared with injected skin samples from rats that received LE-doxy in DPPC liposomes (Fisher's exact test; $P=0.066$ ).

${ }^{c}$ Noninjected skin samples from rats that received LE-doxy in sphing liposomes had a greater probability of having no lesions when compared with noninjected skin samples from rats that received LE-doxy in DPPC liposomes (Fisher's exact test; $P=0.052$ ). 


\section{Doxycycline-loaded Sphingomyelin/Cholesterol Liposomes}

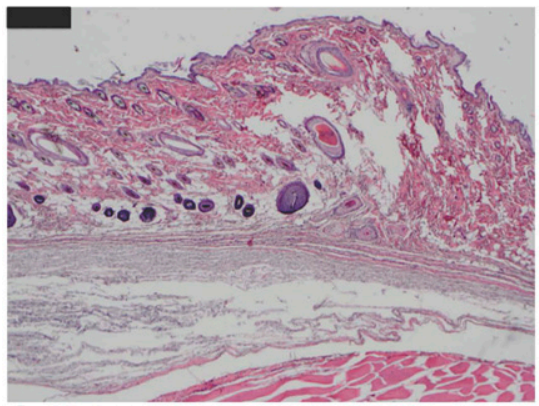

A

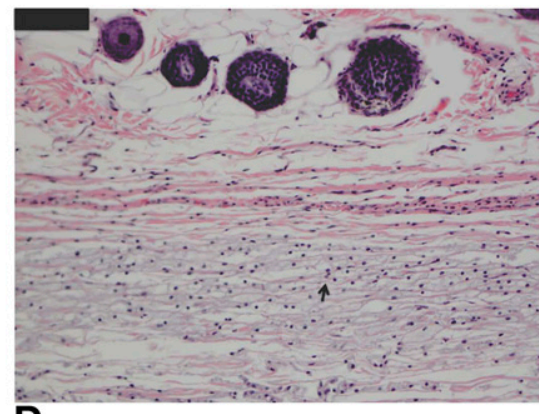

D

Doxycycline-loaded Dipalmitoylphosphatidylcholine/Cholesterol Liposomes

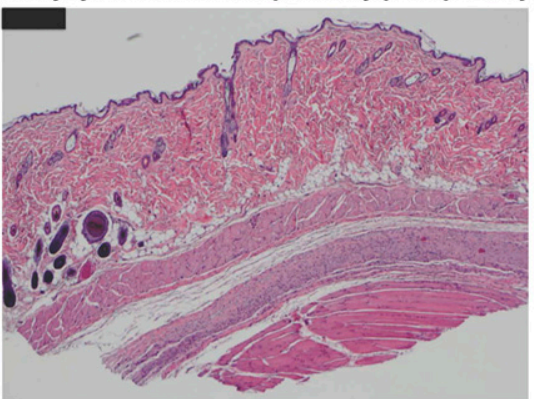

B

Empty Sphingomyelin/Cholesterol Liposomes

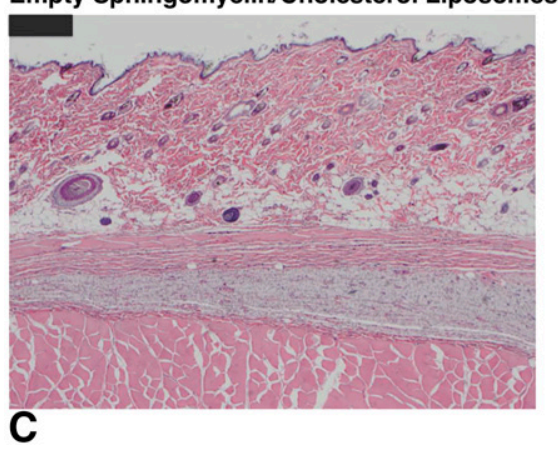

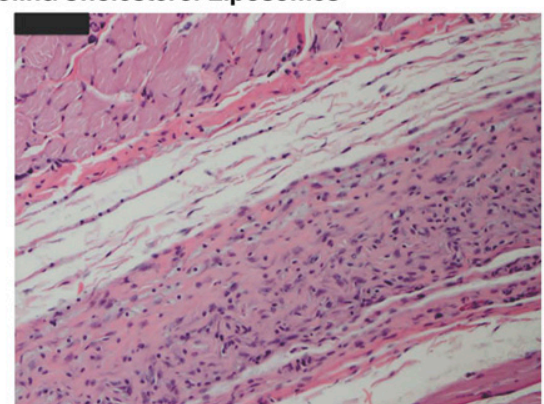

E

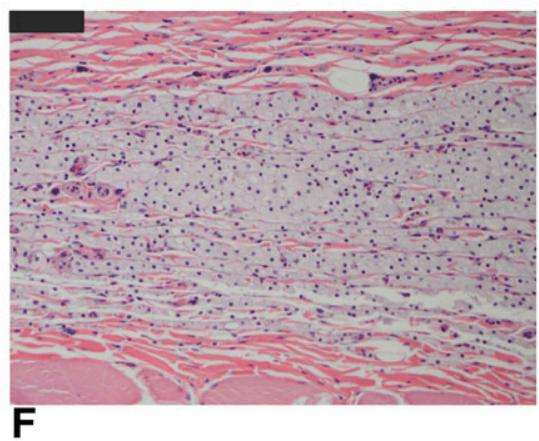

Fig. 3. ACI rat injected with sphing LE-doxy liposomes with mild to moderate histiocytic infiltration of the subcutaneous space (A); rat injected with DPPC LE-doxy with minimal cellular infiltrates (B); and rat injected with blank sphing-cholesterol liposomes with moderate cellular infiltrates $(\mathrm{C}) ; 4 \times$, bar $=200 \mu \mathrm{m}$. ACI rats injected with the same formulations as $(\mathrm{A}-\mathrm{C})$ at $20 \times$, bar $=50 \mu \mathrm{m}$, sphing LE-doxy liposomes (D), DPPC LE-doxy (E), and blank sphing-cholesterol liposomes (F). Cellular detail at the higher magnification includes the foamy cytoplasm of histiocytes with intensely stained nuclei (D, arrow), and the accumulation of histiocytes was not limited to any one group of liposome-injected rats, including those administered blank liposomes $(\mathrm{F})$.
10-40 times more efficient than the previously published methods (Table 4). Previous formulations of doxy in DPPC/cholesterol liposomes used mannose or glucose solutions at a $\mathrm{pH}$ of 6.0 as nonionic hydrating solutions, and these formulations have encapsulation efficiencies of nearly 10-fold less than the sulfuric acid-loading technique (Budai et al., 2009). Ciprofloxacin was loaded into DPPC/ cholesterol large unilamellar vesicles across a transmembrane $\mathrm{pH}$ gradient. The drug forms small stacks in the interior of the liposome and precipitates under certain conditions (Maurer et al., 1998; MaurerSpurej et al., 1999). Drug loading and precipitation were studied using ciprofloxacin and vinorelbine using a hydroxybenzenesulfonate or $\mathrm{MgSO}_{4}$ gradient (Zhigaltsev et al., 2006). Drug precipitation inside the liposome led to better drug retention (Zhigaltsev et al., 2006). Their loading equation predicted that the percentage of drug in the liposome is not dependent on the initial concentration of the drug when there is no precipitate. (Zhigaltsev et al., 2006). The percentage of released drug is dependent on the initial drug concentration, and equilibrium between the soluble drug and precipitate follows a zero-order process if the drug precipitates in the liposome (Zhigaltsev et al., 2006). Tu et al. used an ammonium sulfate gradient-loading system to describe the liposomal loading of the drug based on the amount of ammonium ion in the liposomes and the initial amount of drug added (Tu et al.,
2010). The inverse of the fraction of hydromorphone loaded versus hydromorphone added is linear, and the slope is the inverse amount of the amount of ammonium ions present in the liposome ( $\mathrm{Tu}$ et al., 2010). The fraction of the drug loaded decreases as the amount of the drug added increases, which was not previously described (Zhigaltsev et al., 2006). Ammonium sulfate gradient loading without precipitation produced a concentrated drug within the liposome (Tu et al., 2010). There was no movement of cations across the liposome bilayer. Ammonium $\left(\mathrm{NH}_{4}\right)$ donates a hydrogen ion to the drug, forming ammonia $\left(\mathrm{NH}_{3}\right)$, which diffuses through the lipid bilayer into the solution. The unionized drug is brought into the liposome across the gradient.

We hypothesized doxy would follow this equation, and using hydrogen ions rather than ammonia would further improve the loading. We loaded $8.25 \mathrm{mg} / \mathrm{ml}$ doxy $(\times 4 \mathrm{ml}$ for a $33-\mathrm{mg}$ drug) into DPPC/cholesterol liposomes at $22^{\circ} \mathrm{C}$, which was well below the phase transition temperature of the lipid (Table 1). The loading efficiency for doxy using 3.0 M sulfuric acid was lower for sphing/cholesterol liposomes compared with DPPC/cholesterol, but it was better than other published results (Tables 1 and 4). Sphing LE-doxy loading under the same conditions was less efficient, probably due to the higher phase transition temperature of the sphing, especially since this 

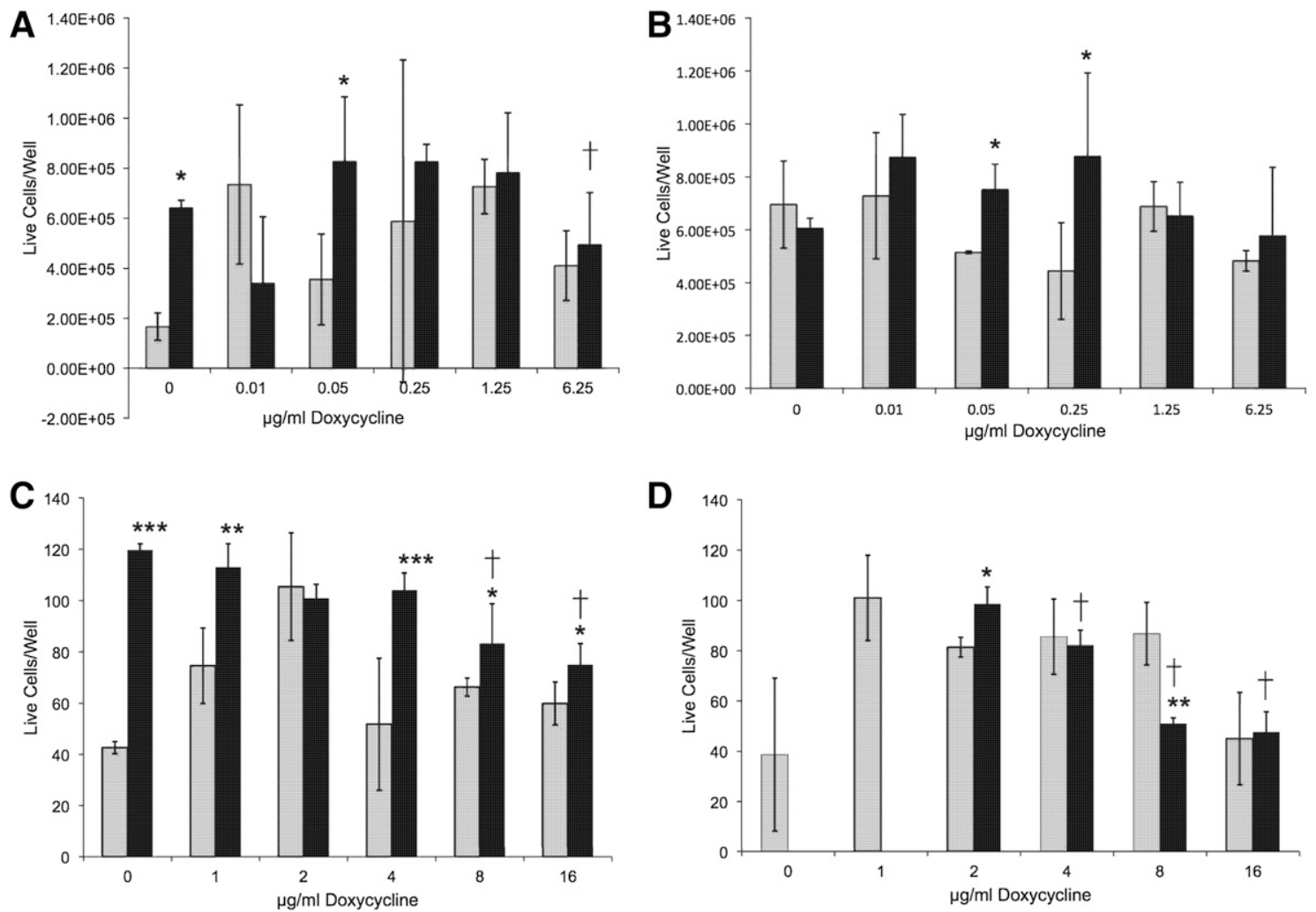

Fig. 4. Cytotoxicity of doxy in uninfected J774A.1 macrophage cells (A and B) and M. smegmatis-infected J774A.1 macrophage cells (C and D) at 24 (A and C) and 48 (B and D) hours after culture. Black bars indicate STD-doxy, and gray bars indicate LE-doxy. Significant differences between cells treated with LE or STD-doxy are indicated as $* P \leq 0.05, * * P \leq 0.01$, or $* * * P \leq 0.001$. Dagger (A, C, and D) indicates a significantly different number of cells between cultures treated with STD-doxy, in which the numbers of drug-treated cells are less than the zero-concentration control or the lowest drug concentration where cells were present to count $(2 \mu \mathrm{g} / \mathrm{ml})(P \leq 0.05)$.

sphingolipid was used along with cholesterol to form the lipid membrane (Szoka and Papahadjopoulos, 1980). The phase transition temperature of the DPPC-cholesterol membranes would be expected to be lower than sphing, the membranes would be less rigid, and $\mathrm{pH}$ gradient loading would be expected to be faster for a gradient of the same number of $\mathrm{pH}$ units between the inner liposome compartments and the outer medium (Szoka and Papahadjopoulos, 1980; Maurer et al., 2001). Loading of sphing liposomes was still adequate for the preparation to be used in in vitro leakage tests and pharmacokinetics studies in rats. DPPC LE-doxy liposomes were large, having a $Z$-average diameter of $3178 \mathrm{~nm}$, and liposomes made using shaking without other disruptive techniques, such as sonication or extrusion, would be expected to be multilamellar (Szoka and Papahadjopoulos, 1980). Large, multilamellar liposomes administered subcutaneously either remain at the injection site and are engulfed by macrophages or are distributed through lymphatic channels (Oussoren and Storm, 1999, 2001). Thin layer chromatography results showed the presence of two additional components, suggesting that DPPC breakdown products were present (Supplemental Fig. 1). Given the exposure of the lipid to acid at elevated temperatures during liposome preparation, it is not unexpected that some lipid would be hydrolyzed in this way (Grit et al., 1993a,b). The effect of the presence of these two lipid degradation products on the liposome membrane integrity in our loading system is presently unknown. The pharmacokinetics (Fig. 2; Table 2) of the liposome preparations and liver concentrations at 4 weeks demonstrated that adequate concentrations of intact liposomes were present in the formulations tested.

Pharmacokinetic analysis of STD-doxy and previous LE-doxy formulations using different loading methodologies has been described by a number of investigators (Blanchard et al., 1975; Saivin and Houin, 1988; Kelly et al., 1992; Sangaré et al., 2001a,b; Selliah and Ravaoarinoro, 2004; Rolain et al., 2005; Agwuh and MacGowan, 2006; Zozaya et al., 2013; Gutierrez et al., 2014). We obtained lower values of AUC, $C_{\max }$, and MRT for STD-doxy when compared with the LE-doxy formulations. Rats administered sphing LE-doxy had a higher $C_{\max }$ and AUC compared with those administered DPPC. The MRT of DPPC LE-doxy was greater than that for sphing LE-doxy. These differences are due to the lipids used for the membranes and the amount of drug loaded in the liposomes. The higher $C_{\max }$ for the liposomal formulations was attributed to an initial burst of drug leakage in both the in vitro and in vivo formulations of LE-doxy and higher doses in comparison with STD-doxy. The refrigerated liposomal preparations are put into $23^{\circ} \mathrm{C}, \mathrm{pH} 7.4$, saline or approximately $37^{\circ} \mathrm{C}, \mathrm{pH} 7.4$, subcutaneous tissues. The change in $\mathrm{pH}$ and temperature caused the drug to efflux until the internal liposomal $\mathrm{pH}$ was stabilized. The initial burst of leakage tended to inhibit further leakage as the internal liposomal $\mathrm{pH}$ dropped.

The 4-week postinjection liver samples had identifiable levels of doxy. The average concentration for sphing LE-doxy was $0.174 \mu \mathrm{g} / \mathrm{g}$ (S.D. \pm 0.0505$)$ and that for DPPC LE-doxy was $0.169 \mu \mathrm{g} / \mathrm{g}$ (S.D. \pm 0.0850 ). STD-doxy has a bioavailability of over $80 \%$ (Agwuh and MacGowan, 2006). Excretory organs, including the liver, contain the highest concentrations (Blanchard et al., 1975; Saivin and Houin, 1988). The serum concentration of injectable doxy reaches a maximum 2-4 hours after injection (Blanchard et al., 1975). The liver/serum ratio decreases until 8 hours and then rises. These two peaks correlate with the low peaks found in the kidney (Blanchard et al., 1975). The MIC of many microorganisms is variable, the $C_{\max }$ of DPPC and 

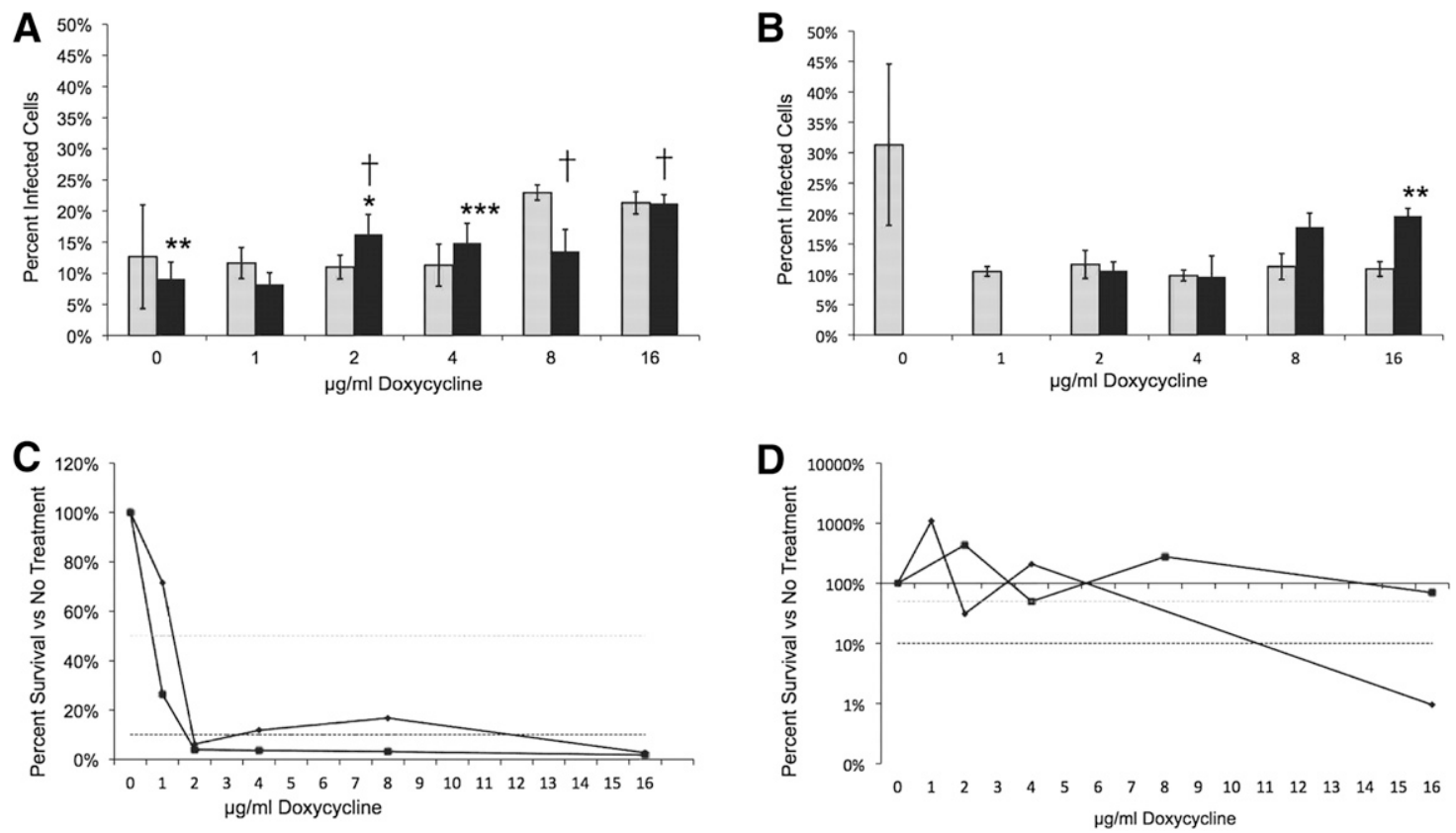

Fig. 5. Colony-forming units and infected cell counts. Fluorescence microscopy of $M$. smegmatis-infected J774A.1 cells stained with propidium iodide and auramine stains at 24 (A) and 48 (B) hours. Percentage viable M. smegmatis (colony-forming units) at increasing concentrations of STD (squares) or LE-doxy (diamonds) at 24 (C) or 48 (D) hours. Black bars indicate STD-doxy, and gray bars indicate LE-doxy. Dotted lines (C and D) are MIC 50 (gray dots) and MIC 90 (black dots). Significant differences between cells treated with LE or STD-doxy are indicated as $* P \leq 0.05, * * P \leq 0.01$, or $* * * P \leq 0.001$. Dagger (A) indicates a significantly different percentage of infected cells between cultures treated with STD-doxy, in which the percentage of drug-treated cells is more than the zero-concentration control $(P \leq 0.05)$.

sphing (2.01 and $6.49 \mu \mathrm{g} / \mathrm{ml}$, respectively) in serum was above the published MIC of organisms, such as Streptococcus pneumoniaie, Group A streptococci, and Staphylococcus aureus (Agwuh and MacGowan, 2006). The MICs for Coxiella burnetii are reported from 1 to $4 \mu \mathrm{g} / \mathrm{ml}$, levels which fall within our serum levels (Rolain et al., 2005). A B-cyclodextrin-based matrix formulation of long-acting doxy had a $C_{\max }$ of $2.8 \pm 0.3$ in dogs (Gutierrez et al., 2014). Mice infected with Chlamydia trachomatis received intramuscular injections of cationic liposomal doxy for 30 days using a $10 \mu \mathrm{g} / \mathrm{ml}$ solution. The $C_{\max }$ was $218.75 \mu \mathrm{g} / \mathrm{ml}$ at 48 hours (sera), $18.25 \mu \mathrm{g} / \mathrm{ml}$ at 24 hours (liver), and $2.3 \mu \mathrm{g} / \mathrm{ml}$ at 12 hours (genital organs) (Selliah and Ravaoarinoro, 2004). Tissues for this study were homogenized in $1 \mathrm{ml}$ of sterile water, and the homogenate was evaluated for bacterial inhibition (Selliah and Ravaoarinoro, 2004). Our 4-week postinjection liver concentrations were lower but were based on the grams wet weight of tissue.

STD-doxy has a pH between 1.8 and 3.3 and is not recommended for i.m. or s.c. use due to the potential for injection site pain, irritation, and tissue necrosis (Zozaya et al., 2013). A nonpainful injection site bulge was reported in dogs receiving a long-acting formulation, although histology was not performed (Gutierrez et al., 2014). There were no skin reactions in our previous studies with liposomal

TABLE 4

Published encapsulation efficiencies of various liposomal-antibiotic formulations

\begin{tabular}{|c|c|c|c|c|c|c|}
\hline Drug Name & Lipid & $\begin{array}{l}\text { Drug } \\
\text { Input }\end{array}$ & $\begin{array}{l}\text { Loading } \\
\text { Efficiency }\end{array}$ & $\begin{array}{l}\text { Milligrams } \\
\text { Loaded }\end{array}$ & $\mathrm{mg} / \mu \mathrm{M}$ & Citation \\
\hline & $\mu M$ & $m g$ & $\%$ & & & \\
\hline \multirow[t]{3}{*}{ Doxycycline } & 90 LEC anionic & 2 & 49.17 & 0.98 & 0.01 & Sangaré et al., 1998, \\
\hline & 90 LEC cationic & 2 & 28.68 & 0.57 & 0.006 & Sangaré \\
\hline & 90 LEC neutral & 2 & 21.06 & 0.42 & 0.004 & Sangaré et al., 1998 \\
\hline \multirow[t]{3}{*}{ Doxycycline } & 90 LEC anionic & 2 & 49.1 & 0.98 & 0.01 & Sangaré et al., 1999 \\
\hline & 90 LEC cationic & 2 & 28.68 & 0.57 & 0.006 & Sangaré et al., 1999 \\
\hline & 90 LEC neutral & 2 & 21 & 0.42 & 0.004 & Sangaré et al., 1999 \\
\hline Doxycycline & 90 LEC cationic & 2 & 28.68 & 0.57 & 0.006 & Sangaré et al., 2001a \\
\hline \multirow[t]{3}{*}{ Doxycycline } & 2.73 DPPC, phosphate & 0.1354 & $15.98(\mathrm{pH} \mathrm{6})$ & 0.02 & 0.007 & Budai et al., 2009, 2009 \\
\hline & & & $16.18(\mathrm{pH} \mathrm{7})$ & 0.02 & 0.008 & \\
\hline & & & $16.29(\mathrm{pH} 8)$ & 0.02 & 0.008 & \\
\hline \multirow[t]{3}{*}{ Doxycycline } & 2.73 DPPC, glucose & 0.1354 & $24.28(\mathrm{pH} 6)$ & 0.03 & 0.01 & Budai et al., 2009 \\
\hline & & & $28.31(\mathrm{pH} \mathrm{7})$ & 0.04 & 0.01 & \\
\hline & & & $21.2(\mathrm{pH} 8)$ & 0.03 & 0.01 & \\
\hline \multirow[t]{3}{*}{ Doxycycline } & 2.73 DPPC mannitol & 0.1354 & $39.47(\mathrm{pH} \mathrm{6})$ & 0.05 & 0.02 & Budai et al., 2009 \\
\hline & & & $30.36(\mathrm{pH} \mathrm{7})$ & 0.04 & 0.01 & \\
\hline & & & $39.47(\mathrm{pH} 8)$ & 0.05 & 0.02 & \\
\hline Doxycycline & $20 \mathrm{DPPC}$ & 8.25 & 97.77 & 8.06 & 0.403 & Current study \\
\hline Doxycycline & 80 sphing & 33 & 43.87 & 14.47 & 0.18 & Current study \\
\hline
\end{tabular}

LEC, egg lecithin. 
morphine, hydromorphone, and oxymorphone tested in rats, dogs, and nonhuman primates (Krugner-Higby et al., 2003, 2009; Smith et al., 2003, 2013). In the present study, STD-doxy-injected skin samples had a greater probability of having no lesions compared with LEDPPC doxy-injected samples. Miscellaneous inflammation was diagnosed in areas of noninjected tissue. Histiocytosis was noted in the blank, DPPC, and sphing liposomes, but clinically did not adversely affect the rats. We found few statistically significant differences between the groups with respect to skin histology (Fisher's exact test), and concluded that the LE-doxy preparations were safe to be given at a dose of $50 \mathrm{mg} / \mathrm{kg}$ s.c. in rats.

The sulfuric acid-loaded liposomes were very large when they were sized. The values obtained reflect the expected substantial size of liposomes made by this method. Large liposomes like these would be expected to be distributed by circulation in the lymphatics and by engulfment by macrophages in the subcutis based on previous experiments using other liposomal formulations (Oussoren and Storm, 1999, 2001).

The efficacy of doxy against cell-associated $M$. smegmatis at 24 hours was similar for both STD and DPPC LE-doxy. However, at 48 hours, none of the concentrations of STD-doxy reached the MIC 90, whereas the liposomal concentration of $16 \mu \mathrm{g} / \mathrm{ml}$ reached the MIC 90, indicating a more effective formulation at that time point (Fig. 5, C and D). Disparities between MIC values at 48 versus 24 hours may be attributed in part to loss of intracellular $M$. smegmatis within dying J774A.1 cells. Uninfected J774A.1 cells treated with STD or DPPC LE-doxy continued to grow for 48 hours, and neither treatment was cytotoxic to the cells. There was no clear evidence of dose-dependent cytotoxicity in uninfected J774A.1 cells. The concentrations of STD and DPPC LE-doxy formulations used in the experiments in the current manuscript were all below the cytotoxic threshold (Fig. 4, A and $\mathrm{B}$ ). This experiment was done to determine if the concentrations used on infected cells were cytotoxic to the cells and not to find a cytotoxic threshold. There were differences in the numbers of liveinfected cells at 24 hours that favored STD-doxy (Fig. 4C). Those differences were not found at 48 hours (Fig. 4, C and D). Experiments in which macrophage-origin J774A.1 cells were treated with liposomal clodronate, a liposomal preparation of a drug that kills macrophages, indicated the cytotoxic effects were greater at 48 hours than at 24 hours (Frith et al., 1997). These and the current study's results may be because the macrophage-origin cells take more than 24 hours to phagocytize enough liposomes to have a maximal effect: cytotoxicity in the case of clodronate and bacterial killing in the case of doxy.

Mycobacterium smegmatis is an environmental mycobacterial species that has been isolated from humans, often in deep tissuesequestered infections or in immunocompromised hosts that are susceptible to doxy (Wallace et al., 1988). Strains of M. smegmatis isolated from human infections displayed a range of MICs from $<0.25 \mu \mathrm{g} / \mathrm{ml}$ to $2-4 \mu \mathrm{g} / \mathrm{ml}$ in non-cell associated assays (Wallace et al., 1988). This is consistent with our study results, which were obtained using the Alamar blue assay after treating M. smegmatis with different concentrations of STD or LE DPPC-doxy. Mycobacteria are thought to persist in the body by establishing stable infections in macrophages (Wallace et al., 1988). Macrophages phagocytize liposomes well, so drugs are targeted to macrophages by liposomal encapsulation (Agrawal and Gupta, 2000, Leemans et al., 2001; Sangaré 2001a,b). Our results indicate DPPC LE-doxy is effective against cell-associated infection with M. smegmatis for a longer period of time than STD-doxy.

In conclusion, two novel formulations of LE-doxy reached measurable and potentially effective concentrations in the serum and liver for 336 hours, were not damaging to the injection sites, showed a lack of cytotoxicity to J774A.1 cells, and had in vitro activity against M. smegmatis. Our sulfuric acid-loading method provided better encapsulation and a longer duration than other passive capture-loading methods for DPPC and sphing liposomes. Further efficacy research is planned for in vivo infectious disease models.

\section{Acknowledgments}

The authors thank the School of Veterinary Medicine vivarium staff for animal care; John Haack and Erin Balay for assistance with the liposomal work; and Matt Warner for determining the liver tissue concentration of doxycycline.

\section{Authorship Contributions}

Participated in research design: Heath, Krugner-Higby, Franklin, Marcus, Talaat.

Conducted experiments: Franklin, Krugner-Higby, Marcus, Sullivan.

Contributed new reagents or analytic tools: KuKanich.

Performed data analysis: Franklin, Krugner-Higby, Marcus, KuKanich.

Wrote or contributed to the writing of the manuscript: Franklin, KrugnerHigby, Heath, Marcus, Talaat, Sullivan, KuKanich.

\section{References}

Agrawal AK and Gupta CM (2000) Tuftsin-bearing liposomes in treatment of macrophage-based infections. Adv Drug Deliv Rev 41:135-146.

Agwuh KN and MacGowan A (2006) Pharmacokinetics and pharmacodynamics of the tetracyclines including glycylcyclines. J Antimicrob Chemother 58:256-265.

Blanchard P, Rudhardt M, and Fabre J (1975) Behaviour of doxycycline in the tissues. Chemotherapy 21 (Suppl 1):8-18.

Bligh EG and Dyer WJ (1959) A rapid method of total lipid extraction and purification. Can J Biochem Physiol 37:911-917.

Budai M, Chapela P, Budai L, Wales ME, Petrikovics I, Zimmer A, Gróf P, and Klebovich I (2009) Liposomal oxytetracycline and doxycycline: studies on enhancement of encapsulation efficiency. Drug Discov Ther 3:13-17.

Denis M, Forget A, Pelletier M, Gervais F, and Skamene E (1990) Killing of Mycobacterium smegmatis by macrophages from genetically susceptible and resistant mice. J Leukoc Biol 47: 25-30.

Federici TJ (2011) The non-antibiotic properties of tetracyclines: clinical potential in ophthalmic disease. Pharmacol Res 64:614-623.

Franzblau SG, Witzig RS, McLaughlin JC, Torres P, Madico G, Hernandez A, Degnan MT, Cook MB, Quenzer VK, and Ferguson RM, et al. (1998) Rapid, low-technology MIC determination with clinical Mycobacterium tuberculosis isolates by using the microplate Alamar Blue assay. $J$ Clin Microbiol 36:362-366.

Frith JC, Mönkkönen J, Blackburn GM, Russell RGG, and Rogers MJ (1997) Clodronate and liposome-encapsulated clodronate are metabolized to a toxic ATP analog, adenosine $5^{\prime}$-( $\beta$, $\gamma$-dichloromethylene) triphosphate, by mammalian cells in vitro. $J$ Bone Miner Res 12: 1358-1367.

Ghosh P, Wu CW, and Talaat AM (2013) Key role for the alternative sigma factor, SigH, in the intracellular life of Mycobacterium avium subsp. paratuberculosis during macrophage stress. Infect Immun 81:2242-2257.

Grit M, Underberg WJM, and Crommelin DJA (1993a) Hydrolysis of saturated soybean phosphatidylcholine in aqueous liposome dispersions. J Pharm Sci 82:362-366.

Grit M, Zuidam NJ, Underberg WJM, and Crommelin DJA (1993b) Hydrolysis of partially saturated egg phosphatidylcholine in aqueous liposome dispersions and the effect of cholesterol incorporation on hydrolysis kinetics. J Pharm Pharmacol 45:490-495.

Gu Y, Walker C, Ryan ME, Payne JB, and Golub LM (2012) Non-antibacterial tetracycline formulations: clinical applications in dentistry and medicine. J Oral Microbiol 4:19227.

Gutiérrez L, Ocampo L, Espinosa F, and Sumano H (2014) Pharmacokinetics of an injectable long-acting parenteral formulation of doxycycline hyclate in pigs. $J$ Vet Pharmacol Ther 37: 83-89.

Heath TD, Krugner-Higby LA, Smith LJ, Tu S, Kalkhof N, and Franklin RK (2014) inventors, Comfort Care For Animals, Llc, assignee. Encapsulating liposomes. U.S. patent PCT/US2013/ 060305. 2014 Mar 27

Henao J, Sánchez D, Muñoz CH, Mejía N, Arias MA, García LF, and Barrera LF (2007) Human splenic macrophages as a model for in vitro infection with Mycobacterium tuberculosis. Tuberculosis (Edinb) 87:509-517.

Hunt CA, Rustum YM, Mayhew E, and Papahadjopoulos D (1979) Retention of cytosine arabinoside in mouse lung following intravenous administration in liposomes of different size. Drug Metab Dispos 7:124-128

Julious SA and Debarnot CAM (2000) Why are pharmacokinetic data summarized by arithmetic means? J Biopharm Stat 10:55-71.

Kelly DJ, Chulay JD, Mikesell P, and Friedlander AM (1992) Serum concentrations of penicillin, doxycycline, and ciprofloxacin during prolonged therapy in rhesus monkeys. J Infect Dis 166: 1184-1187.

Krugner-Higby L, KuKanich B, Schmidt B, Heath TD, Brown C, and Smith LJ (2009) Pharmacokinetics and behavioral effects of an extended-release, liposome-encapsulated preparation of oxymorphone in rhesus macaques. J Pharmacol Exp Ther 330:135-141.

Krugner-Higby L, Smith L, Clark M, Heath TD, Dahly E, Schiffman B, Hubbard-VanStelle S, Ney D, and Wendland A (2003) Liposome-encapsulated oxymorphone hydrochloride provides prolonged relief of postsurgical visceral pain in rats. Comp Med 53:270-279.

Kumar R and Malik JK (1998) Some pharmacokinetic parameters and dosage regimens for a long-acting formulation of oxytetracycline in 6- to 8-month-old male calves. Vet Res Commun 22:533-544. 
Leemans JC, Juffermans NP, Florquin S, van Rooijen N, Vervoordeldonk MJ, Verbon A, van Deventer SJH, and van der Poll T (2001) Depletion of alveolar macrophages exerts protective effects in pulmonary tuberculosis in mice. J Immunol 166:4604-4611.

Maurer N, Fenske DB, and Cullis PR (2001) Developments in liposomal drug delivery systems. Expert Opin Biol Ther 1:923-947.

Maurer N, Wong KF, Hope MJ, and Cullis PR (1998) Anomalous solubility behavior of the antibiotic ciprofloxacin encapsulated in liposomes: a 1H-NMR study. Biochim Biophys Acta 1374:9-20.

Maurer-Spurej E, Wong KF, Maurer N, Fenske DB, and Cullis PR (1999) Factors influencing uptake and retention of amino-containing drugs in large unilamellar vesicles exhibiting transmembrane $\mathrm{pH}$ gradients. Biochim Biophys Acta 1416:1-10.

Nelson ML and Levy SB (2011) The history of the tetracyclines. Ann N Y Acad Sci 1241 $17-32$.

Omri A and Ravaoarinoro M (1996) Preparation, properties and the effects of amikacin, netilmicin and tobramycin in free and liposomal formulations on Gram-negative and Gram-positive bacteria. Int J Antimicrob Agents 7:9-14.

Omri A, Ravaoarinoro M, and Poisson M (1995) Incorporation, release and in-vitro antibacterial activity of liposomal aminoglycosides against Pseudomonas aeruginosa. J Antimicrob Che mother 36:631-639.

Oussoren C and Storm G (1999) Role of macrophages in the localisation of liposomes in lymph nodes after subcutaneous administration. Int J Pharm 183:37-41.

Oussoren C and Storm G (2001) Liposomes to target the lymphatics by subcutaneous administration. Adv Drug Deliv Rev 50:143-156.

Raabe BM, Lovaglio J, Grover GS, Brown SA, Boucher JF, Yuan Y, Civil JR, Gillhouse KA, Stubbs MN, and Hoggatt AF, et al. (2011) Pharmacokinetics of cefovecin in cynomolgus macaques (Macaca fascicularis), olive baboons (Papio anubis), and rhesus macaques (Macaca mulatta). J Am Assoc Lab Anim Sci 50:389-395.

Rolain JM, Boulos A, Mallet MN, and Raoult D (2005) Correlation between ratio of serum doxycycline concentration to MIC and rapid decline of antibody levels during treatment of $\mathrm{Q}$ fever endocarditis. Antimicrob Agents Chemother 49:2673-2676.

Saivin S and Houin G (1988) Clinical pharmacokinetics of doxycycline and minocycline. Clin Pharmacokinet 15:355-366.

Sangaré L, Morisset R, Gaboury L, and Ravaoarinoro M (2001a) Effects of cationic liposomeencapsulated doxycycline on experimental Chlamydia trachomatis genital infection in mice. $J$ Antimicrob Chemother 47:323-331.

Sangaré L, Morisset R, Omri A, and Ravaoarinoro M (1998) Incorporation rates, stabilities, cytotoxicities and release of liposomal tetracycline and doxycycline in human serum. J Antimicrob Chemother 42:831-834.

Sangaré L, Morisset R, and Ravaoarinoro M (1999) In-vitro anti-chlamydial activities of free and liposomal tetracycline and doxycycline. J Med Microbiol 48:689-693.
Sangaré L, Morisset R, and Ravaoarinoro M (2001b) [In vitro inhibition of Chlamydia trachomatis growth by liposome-encapsulated cyclines]. Pathol Biol (Paris) 49:53-56.

Sapadin AN and Fleischmajer R (2006) Tetracyclines: nonantibiotic properties and their clinical implications. J Am Acad Dermatol 54:258-265.

Selliah S and Ravaoarinoro M (2004) Pharmacokinetics of cationic liposome-encapsulated doxycycline in mice challenged with genital infection by Chlamydia trachomatis. Chemotherapy 50:17-21.

Smith LJ, Krugner-Higby L, Clark M, Wendland A, and Heath TD (2003) A single dose of liposome-encapsulated oxymorphone or morphine provides long-term analgesia in an anima model of neuropathic pain. Comp Med 53:280-287.

Smith LJ, Kukanich BK, Krugner-Higby LA, Schmidt BH, and Heath TD (2013) Pharmacokinetics of ammonium sulfate gradient loaded liposome-encapsulated oxymorphone and hydromorphone in healthy dogs. Vet Anaesth Analg 40:537-545.

Stegemann MR, Sherington J, and Blanchflower S (2006a) Pharmacokinetics and pharmacodynamics of cefovecin in dogs. $J$ Vet Pharmacol Ther 29:501-511.

Stegemann MR, Sherington J, Coati N, Brown SA, and Blanchflower S (2006b) Pharmacokinetics of cefovecin in cats. $J$ Vet Pharmacol Ther 29:513-524.

Szoka F, Jr and Papahadjopoulos D (1980) Comparative properties and methods of preparation of lipid vesicles (liposomes). Annu Rev Biophys Bioeng 9:467-508.

Tu S, McGinnis T, Krugner-Higby L, and Heath TD (2010) A mathematical relationship for hydromorphone loading into liposomes with trans-membrane ammonium sulfate gradients. $J$ Pharm Sci 99:2672-2680

Wallace RJ, Jr, Nash DR, Tsukamura M, Blacklock ZM, and Silcox VA (1988) Human disease due to Mycobacterium smegmatis. J Infect Dis 158:52-59.

Zeidner NS, Massung RF, Dolan MC, Dadey E, Gabitzsch E, Dietrich G, and Levin ML (2008) A sustained-release formulation of doxycycline hyclate (Atridox) prevents simultaneous infection of Anaplasma phagocytophilum and Borrelia burgdorferi transmitted by tick bite. J Med Microbiol 57:463-468.

Zhigaltsev IV, Maurer N, Edwards K, Karlsson G, and Cullis PR (2006) Formation of drugarylsulfonate complexes inside liposomes: a novel approach to improve drug retention. $J$ Control Release 110:378-386.

Zozaya H, Gutierrez L, Bernad MJ, and Sumano H (2013) Pharmacokinetics of a peroral single dose of two long-acting formulations and an aqueous formulation of doxycycline hyclate in horses. Acta Vet Scand 55:21.

Address correspondence to: Rebekah K. Franklin, 396 Enzyme Institute, 1710 University Ave., Madison, WI 53726. E-mail: franklin@rarc.wisc.edu 